\title{
Hard-bottom succession of subtidal epibenthic communities colonizing hidden and exposed surfaces off northern Chile
}

\author{
ALDO S. PACHECO ${ }^{1,2}$, JÜRGEN LAUDIEN ${ }^{1,3}$, MARTIN THIEL ${ }^{4,5}$, OLAF HEILMAYER ${ }^{1}$ \\ and MARCELO OLIVA ${ }^{2}$ \\ ${ }^{1}$ Alfred Wegener Institute for Polar and Marine Research, D-27568 Bremerhaven, Germany. \\ E-mail: babuchapv@yahoo.com \\ ${ }^{2}$ Facultad de Recursos del Mar, Universidad de Antofagasta, P.O. Box 170, Av. Angamos 601, Antofagasta, Chile. \\ ${ }^{3}$ Institute for Applied Ecology Ltd, D-18184 Broderstorf, Germany. \\ ${ }^{4}$ Facultad de Ciencias del Mar, Universidad Católica del Norte, Larrondo 1281, Coquimbo, Chile. \\ ${ }^{5}$ Centro de Estudios Avanzados en Zonas Áridas (CEAZA), Coquimbo, Chile.
}

\begin{abstract}
SUMMARY: The biodiversity of hard-bottom substrata comprises species growing on exposed rock and in hidden microhabitats, such as cracks and crevices. This study examines the succession of epibenthic organisms colonizing an artificial substratum with one surface exposed and one surface hidden on a vertical wall off northern Chile. On each sampling date species coverage of three replicate panels on both surfaces was assessed. The hidden surface was dominated in terms of coverage by the bryozoans Membranipora isabelleana and Lagenicella variabilis, while algae were absent. In contrast, the exposed surface was dominated by encrusting red corallines and the red alga Rhodymenia corallina. At the end of the experimental period both surfaces were dominated by colonial suspension feeders, but showed a different community structure and successional pattern. On the exposed surface, competitive exclusion was identified as an important aspect of succession, whereas on the hidden surface this pattern was not observed. These findings have implications for overall biodiversity, because pioneer species that are not able to survive long periods on exposed surfaces become restricted to hidden surfaces, from where they spread laterally. Thus, hidden microhabitats provide refuges for certain species, and may play an important role in the overall succession on rock faces. We conclude that examination of hidden microhabitats is necessary in order to fully understand succession in hard-bottom habitats.
\end{abstract}

Keywords: habitat complexity, epibenthic hard-bottom communities, succession, Peninsula Mejillones, Humboldt Current System.

RESUMEN: SUCESIÓN DE COMMUNIDADES EPIBENTÓNICAS DE FONDOS DUROS SUBMAREALES COLONIZANDO SUPERFICIES OCULTAS Y EXPUESTAS EN EL NORTE DE CHILE. - La biodiversidad en sustratos de fondo duro está compuesta por especies que crecen en las superficies expuestas de las rocas así como también aquellas presentes en microhábitats ocultos como grietas y cavidades. Este estudio examina el proceso de sucesión de organismos epibentónicos que colonizan un sustrato artificial presentando una superficie expuesta y una oculta en una pared vertical en la península de Mejillones en el norte de Chile. Cada tres meses, tres paneles fueron colectados y en el laboratorio se cuantificó la cobertura de especies en ambas superficies. Durante la sucesión en las superficies ocultas los briozoos Membranipora isabelleana y Lagenicella variabilis dominaron la comunidad en términos de cobertura notándose una ausencia total de algas. En contraste, las algas coralinas custrosas y Rhodymenia corallina fueron componentes importantes de las comunidades que colonizaron las superficies expuestas. La estructura comunitaria y los patrones de sucesión fueron diferentes en ambas superficies, observándose una tendencia a la dominancia de los animales coloniales suspensívoros. En las superficies expuestas se identificó la exclusión competitiva como un proceso importante durante la sucesión, mientras que en las superficies ocultas este patrón no se observó. Esto tiene implicaciones en la biodiversidad general, debido a que las especies pioneras que no pudieron sobrevivir periodos largos en las superficies expuestas, se restringen a los hábitats ocultos desde donde pueden crecer lateralmente. Los microhábitats ocultos proporcionan refugios para algunas especies, lo que puede afectar la sucesión en hábitats rocosos. Concluimos que es necesario examinar los microhábitats ocultos para poder tener un total entendimiento de la sucesión en hábitats de fondos duros.

Palabras clave: complejidad del hábitat, comunidades epibentónicas de fondos duros, sucesión, península Mejillones, Sistema de la Corriente de Humboldt. 


\section{INTRODUCTION}

Natural shallow subtidal rocky habitats are structured heterogeneously. Variable slope, topography, orientation, angle and the characteristics of the substratum have major consequences for the small-scale variability of abiotic and biotic factors (i.e. light intensity, currents, sediment and detritus accumulation, and barriers to predators), and thereby influence the establishment of epibenthic organisms (Witman and Dayton, 2001; Miller and Etter, 2008). In temperate zones, subtidal vertical rocky walls are often dominated by epibenthic suspension feeders while numerous macroalgal species flourish on horizontal substrata, where they benefit from high levels of incoming light (Baynes, 1999; see review in Witman and Dayton, 2001). A range of distinct microhabitats can be noted, from fully exposed horizontal and vertical plain surfaces (Glasby, 2000; Glasby and Connell, 2001) to completely sheltered or hidden habitats such as shaded surfaces, crevices, undersides of boulders, cracks, cavities and even large caves (Jackson, 1977; Glasby, 1999a,b; Richter et al., 2001). Hidden microhabitats also occur beneath or within biogenic substrata, including kelp canopies (Melville and Connell, 2001; Villegas et al., 2008) and foliose corals (Jackson, 1977; Richter et al., 2001). These hidden microhabitats can be important for the survival of poorly competitive epibenthic species. Firstly, they provide refuge from consumers during settlement, post-settlement and juvenile growth (Coyer et al., 1993; Raimondi and Morse, 2000; Roleda et al., 2007). Secondly, hidden microhabitats may alleviate competition, both from species that dominate in more exposed habitats (Irving and Connell, 2002; Miller and Etter, 2008) and between congeners (Navarrete et al., 2008). Thirdly, such habitats may serve as refuges from harmful abiotic conditions such as strong currents or solar radiation (e.g. Burnaford, 2004). The vast majority of studies analysing the main factors influencing subtidal rocky community composition have been conducted using plain, exposed surfaces (e.g. Sebens, 1986; Siddon and Witman, 2004). However, species that first settle on inner (hidden) rock surfaces, from which they later spread onto exposed surfaces, form an important component of the community.

Succession on exposed, hard-bottom epibenthic communities off the coasts of northern and central Chile typically follow a sequence of early, mid- and late colonisation in which competitive exclusion is an important driving factor (Navarrete and Castilla, 2003; Valdivia et al., 2005; Cifuentes et al., 2007). Hidden habitats are likely to be colonised by different communities but species interactions and processes involved in shaping such communities are not well known. Previous studies have mentioned a conspicuous absence of macroalgae in hidden and shaded habitats, which leads to a dominance of invertebrates (Irving and Connell, 2002). At such sites competitive exclusion might be limited or masked by other limitations such as restricted food supply (Baynes, 1999; Richter et al., 2001). Settlement in hidden habitats can be species- or site-specific but the type and strength of post-settlement interactions might also depend on the species composition of adjacent exposed surfaces. Differences between hidden and exposed communities are to be expected, but the interactions and processes involved require evaluation.

To analyse whether the succession process differs between hidden and exposed microhabitats, artificial substratum units with hidden and exposed surfaces were installed on a vertical rock wall off northern Chile. Communities developing on the exposed and hidden surfaces were analysed sequentially over a 27-month period. The aims were (i) to describe the succession of epibenthic organisms colonizing the distinct substratum surfaces, and (ii) to identify the mechanisms driving the community pattern.

\section{MATERIALS AND METHODS}

\section{Study site}

This study was carried out in the northern-central region of the coastal Humboldt Current System (HCS) at a vertical rock face known as the "Anemone Wall" (AW) at $23^{\circ} 28^{\prime} \mathrm{S}, 70^{\circ} 37^{\prime} \mathrm{W}$ off Peninsula Mejillones (near Isla Santa María), northern Chile. Peninsula Mejillones is one of the most productive upwelling centres along the northern coast of Chile. A detailed description of the physical oceanography of the area is available in Escribano et al. (2002). Forming part of a small embayment, AW extends from the shallow subtidal down to $50 \mathrm{~m}$ depth. From the surface to $13 \mathrm{~m}$ the benthic community is dominated by the kelp Lessonia trabeculata. From $13 \mathrm{~m}$ down to $30 \mathrm{~m}$ kelp abundance is substantially reduced and the dominant organisms are relatively small epibenthic taxa, such as filamentous and en- 


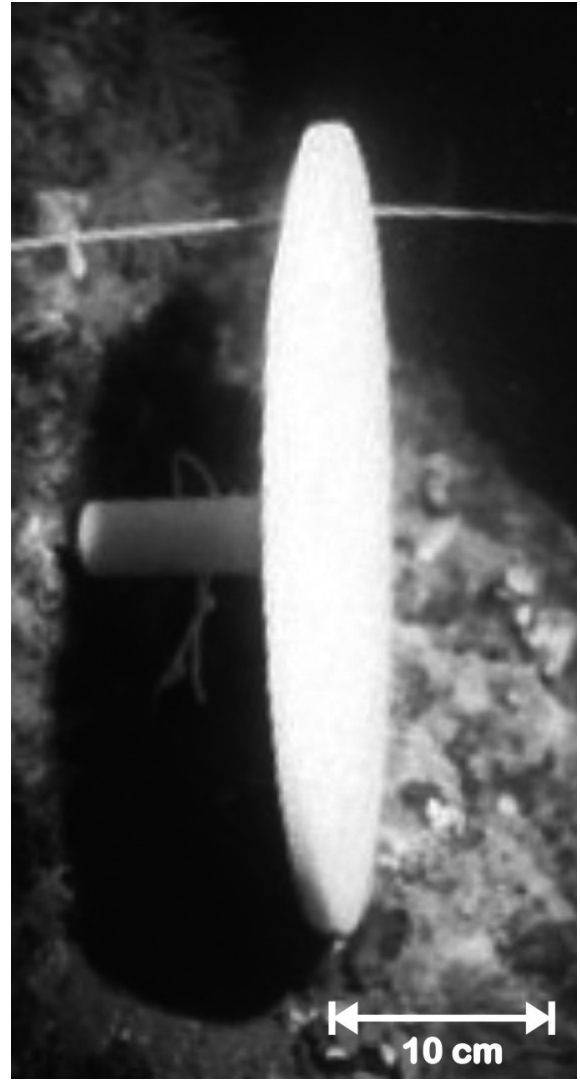

FIG. 1. - Experimental polyethylene panel installed at $17 \mathrm{~m}$ water depth.

crusting red algae, bryozoans, sponges and vermetid gastropods (Pacheco and Laudien, 2008). Since a similar community composition was observed in surrounding vertical rocky areas, the community studied on AW can be considered representative of the exposed coast of Peninsula Mejillones (A. Pacheco, unpublished data).

\section{Experimental design}

In January 2006, 24 circular polyethylene panels (white, $40 \mathrm{~cm}$ in diameter, $1.5 \mathrm{~cm}$ thick, Fig. 1) were installed at AW. This material was chosen because it provides a clean habitat surface of uniform size, complexity and history (see also Underwood and Chapman, 2006). Polyethylene has been shown to avoid bias due to selective larval settlement or substratum rejection, because its neutral charge does not influence natural biochemical conditioning (Dexter and Lucas, 1985; Rodríguez et al., 1993). The experimental panels were installed in an approximately horizontal line along a $60-\mathrm{m}$-section of the wall between 15 and $17 \mathrm{~m}$ depth. The distance between panels varied from 1 to $3 \mathrm{~m}$ depending on the relief of the rock wall. The panels were roughened with sand paper (grade No. 60) in order to provide a homogeneous surface structure (Bourget et al., 1994). The circular shape ensured that edge effects were equal along the border of the circular sampling area. To install panels at AW, holes were drilled and wall plugs inserted. Thereafter, adaptors (a polyethylene cylinder $13.5 \mathrm{~cm}$ long and $4 \mathrm{~cm}$ in diameter) were screwed into each wall plug. The distance between panels and the rock wall was approximately $16 \mathrm{~cm}$. At regular intervals of 3, 6, 9, 12, 15, 18, 21, 24 and 27 months, three panels were randomly chosen, detached and placed carefully into individual mesh bags. Each bag was deposited in an individual plastic container filled with seawater and carefully transported to the laboratory. All panels were treated in the same way, so the potential methodological error was equal and allowed comparison.

\section{Species identification and quantification}

All taxa found on the exposed and hidden surface of the experimental panels were individually identified to the lowest taxonomic level possible. Benthic diatoms were registered and identified at the beginning of the experiment but were excluded from further analysis in order to avoid possible problems due to comparisons of species from very different size spectra. The percent coverage of sessile taxa was estimated counting 130 intersection points from a circular grid (38 $\mathrm{cm}$ diameter) projected onto the centre of both panel surfaces. The circular central area covered by the nutadaptor $\left(50.2 \mathrm{~cm}^{2}\right)$ was excluded from the analyses of both surfaces. Quantification and identification was always conducted by the same person counting from a fixed position above the panel in order to reduce methodological bias.
Abiotic factors
Light intensity readings for both sides of the panels were obtained with a HOBO light data logger (MicroDAQ Ltd, USA). The logger was fixed with cable ties to the respective panel surface, where it recorded light intensity for three successive days of full sun (24-27th April 2008) using three different panels. Differences in light intensity between hidden and exposed surfaces were evaluated using the non- parametric Mann-Whitney test.
Current velocity was assessed for both surfaces by measuring the mass loss from dissolution of gyp- 
sum half-spheres $(3 \mathrm{~cm}$ diameter, $2 \mathrm{~cm}$ radius, initial dry masses ranging between 9.45 and $12.24 \mathrm{~g}$ ). The mass loss has been shown to be directly proportional to current velocity (Yund et al., 1991). Three pairs of gypsum blocks were attached to three newly installed panels, one block on each side. The panels were placed haphazardly along the experimental row. The gypsum blocks were retrieved after $24 \mathrm{~h}$ exposure time, dried and their mass was recorded. Differences in percent mass loss per block between exposed and hidden surfaces were evaluated with a $t$-test. Statistical analyses were conducted using the Minitab software, release 14 for MS Windows.

\section{Statistical analysis}

Differences in community composition between different sampling dates (months 3 to 27) and surfaces were tested using one-way analysis of similarity, ANOSIM. This is a non-parametric procedure, in which the difference between average ranked Bray-Curtis dissimilarity values (square root transformed) among replicates, between treatments and within treatments is used to calculate an R-statistic (Clarke, 1993). When the global R-value of the ANOSIM test was significant $(\mathrm{p}<0.05)$, pairwise comparisons were conducted. Therefore, the interpretation of pairwise comparisons was based on R-values (rather than p) as recommended by Clarke and Gorley (2006), because with three replicates for each sampling date the significance level cannot be lower than $\mathrm{p}=0.1$. These authors stated that the level of significance is very dependent on the number of replicates in the comparison, and thus always influenced by the sample size. R, on the other hand, is largely unaffected by the number of replicates (i.e. possible permutations) and gives an absolute measure of differences between two or more groups in the high-dimensional space of the data. In order to facilitate and visualise the interpretation of pairwise comparisons, an nmMDS plot was constructed from a dissimilarity matrix calculated from Euclidian distances between Rvalues. To test whether community succession on the different panel surfaces underwent trajectory or sequential changes over time, a seriation with replication routine was run using the RELATE analysis. Dissimilarity matrix, nmMDS ordination plots, ANOSIM and RELATE seriation analyses were performed using the PRIMER v6 software package (Clarke and Gorley, 2006).

\section{RESULTS}

\section{Measurements of light and currents}

During the three 24-h cycles, hidden surfaces received only $9 \%$ of the light intensity measured at exposed surfaces $\left(1.2 \pm \mathrm{SD} 5.19 \mathrm{lum} \mathrm{m}^{-2}\right.$ compared to $13.01 \pm$ SD $75.62 \mathrm{lum} \mathrm{m}^{-2}$ ). The difference was significant (Mann-Whitney U-test; U $=346.57$, $\mathrm{df}=1, \mathrm{p}<0.05)$. Mass losses of gypsum half-spheres installed on exposed $(6.46 \pm 1.11 \mathrm{~g})$ and hidden $(7.05 \pm 5.24 \mathrm{~g})$ sides of the panels were not significantly different $(t$-test; $\mathrm{T}=0.92, \mathrm{p}>0.05)$.

\section{Species cover during succession on exposed versus hidden panel sides}

On both surfaces, succession started with benthic diatoms (Navicula sp., Nitzschia sp., Cocconeis sp., Amphora sp., and Cocinodiscus sp.). From the beginning, young sporophytes of Rhodymenia coralli$n a$ were only present on the exposed surface. Here, encrusting red corallines appeared after six months and persisted with about $30 \%$ coverage for most of the experiment, while abundances of the bryozoan Membranipora isabelleana were lower (Fig. 2). For these two species coverage on exposed surfaces remained constant, with a slight increase in abundance after one year. After 15 months, a strong recruitment of the barnacle Balanus flosculus $(60.8 \%$ of total cover) was observed (Fig. 2). Three months later, the abundance of $B$. flosculus on exposed surfaces was reduced to $40 \%$ and the bryozoan Lagenicella variabilis occupied most of the space. $L$. variabilis abundance increased progressively from $33.8 \%$ at 24 months to $70 \%$ at the end of the experiments, finally monopolising the available space on the exposed experimental substrata (Fig. 2). Thus, on exposed surfaces, community succession occurred in a clear transitional manner from early (encrusting red corallines and M. isabelleana), via mid- (B. flosculus) to late (L. variabilis) colonizers (see below).

In contrast to exposed surfaces, hidden surfaces lacked macroalgae and were colonised instead by the bryozoan $M$. isabelleana after three months. Coverage by this species increased progressively to a maximum of $67.2 \%$ cover after one year of exposure. L. variabilis appeared after 9 months and achieved $18.9 \%$ coverage before it decreased to $5.4 \%$, and then resurged at month 18 to reach $20 \%$ after 27 months of exposure (Fig. 2). B. flosculus 


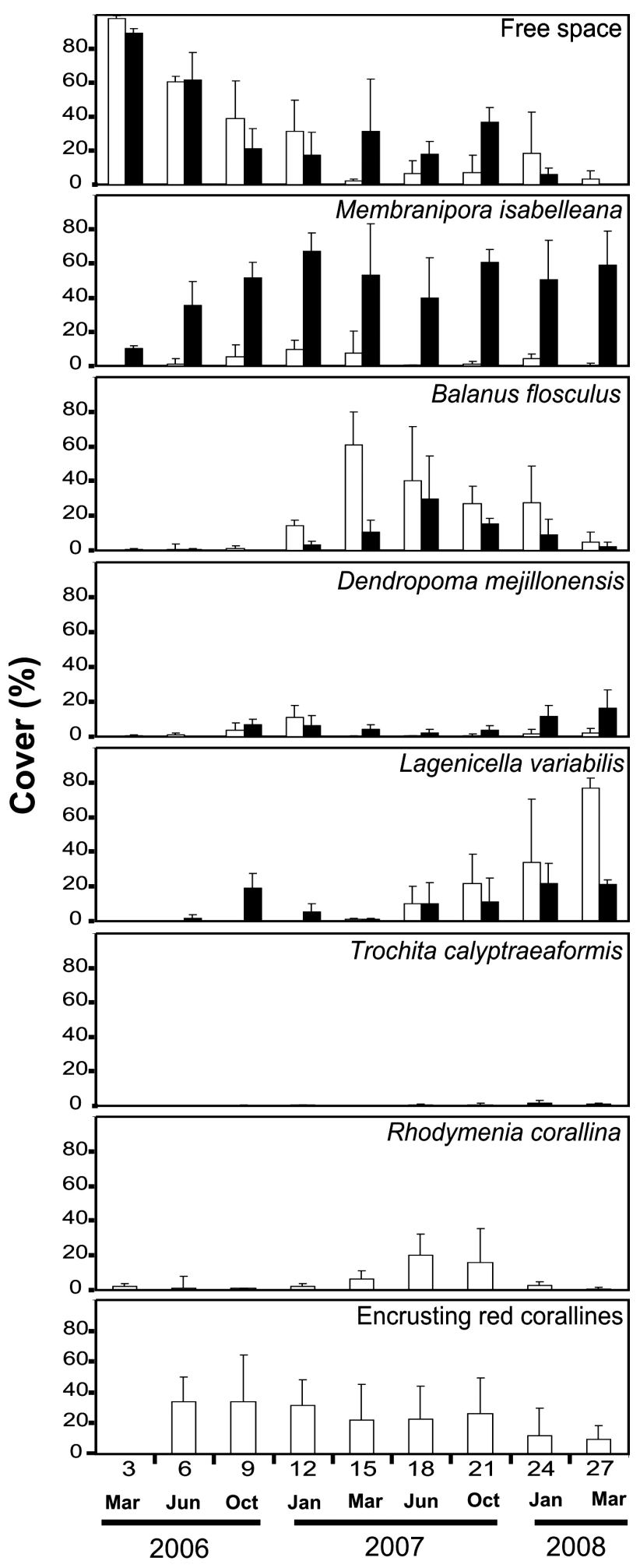

FIG. 2. - Mean percentage $( \pm S D, n=3)$ cover of epibenthic species colonizing exposed (white bars) and hidden (black bars) surfaces during successional development. Numbers at the $\mathrm{x}$-axis indicate the months after the panel's exposure.

recruited after one year and reached its maximum coverage $(29.9 \%)$ after 18 months, before decreas- ing to $8.8 \%$ towards the end of the experiment. The vermetid gastropod Dendropoma mejillonensis was present in low abundance throughout the experiment (Fig. 2). The gastropod Trochita calyptraeaformis and the white anemone Anthothoe chilensis occurred in very low percentages of cover and only on hidden surfaces. During the study period succession on hidden surfaces did not follow a clear sequence of development, as no substantial replacement of species was observed. The early colonizing $M$. isabelleana occupied most of the available substratum throughout the experiment, even though it appeared to be overgrown by the late colonizer $L$. variabilis.

\section{Temporal variation during successional development on exposed and hidden surfaces}

The nmMDS ordination plot derived from the communities of exposed and hidden surfaces showed two separate groups (Fig. 3). ANOSIM indicated differences in community composition between sampling dates and between exposed and hidden surfaces $(\mathrm{R}=0.71, \mathrm{p}<0.05)$.

For exposed communities, one-way ANOSIM detected significant differences in composition on different sampling dates $(\mathrm{R}=0.732, \mathrm{p}<0.05)$. A pairwise comparison nmMDS plot (Fig. 3) showed that the dissimilarities were greater between wellseparated sampling dates (e.g. 3 vs 12 or 9 vs 24 months) than consecutive samplings (6 vs 9,12 vs 15,15 vs 18,18 vs 21,24 vs 27 months). The community compositions observed at consecutive samplings mostly overlapped, indicating that the community developed through progressive changes. The modification in taxonomic composition (i.e. arrival of colonizers) takes at least 6 months. The seriation analysis (RELATE routine) indicated a clear tendency towards seriation $(\rho=0.977, p<0.05)$, confirming a sequential pattern of succession.

Communities found on hidden surfaces also showed significant differences between sampling dates (ANOSIM, $\mathrm{R}=0.47, \mathrm{p}<0.05$ ). The $\mathrm{nmMDS}$ plot of pairwise comparisons (Fig. 3) indicated that the developing community recorded early in the experiment (months 3 and 6) was highly dissimilar to the ones observed in established stages. Some overlap in composition between the community snapshots recorded at months $12,15,18$ and 21 was observed, but there were distinct differences in composition between these and the more established community that emerged after 24 and 27 months and 


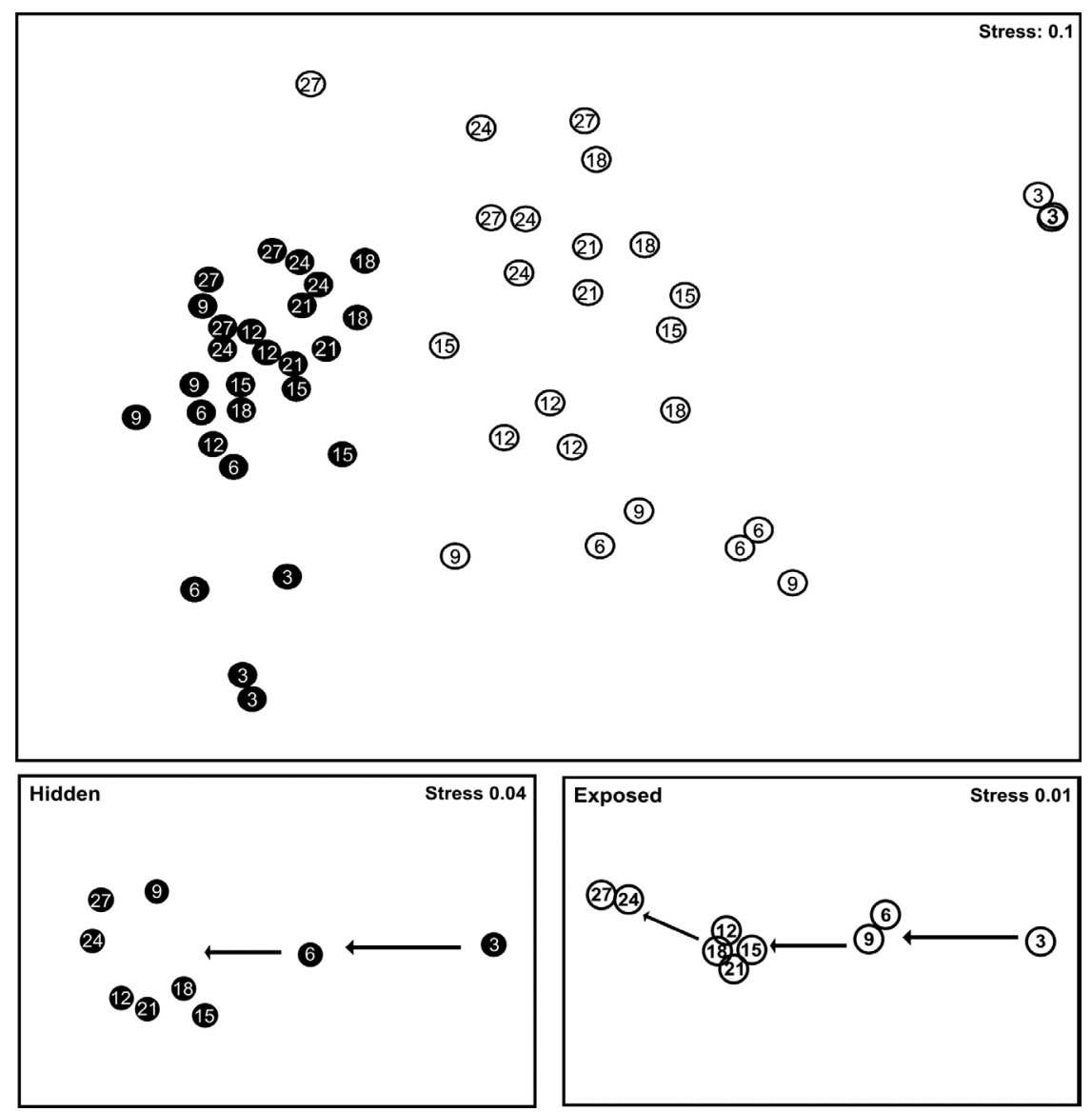

FIG. 3. - Non-metric MDS plot (upper) derived from Bray-Curtis measures with square-root-transformed data of communities developed on exposed surfaces (open circle) and hidden surfaces (filled circle). Non-metric MDS plots derived from Euclidian distance calculated from the R-values resulting from pairwise comparisons after ANOSIM from communities developed on exposed surfaces and hidden surfaces. Numbers indicate the months after the panel's exposure.

also with communities after 9 months of development. The RELATE seriation analysis indicated a tendency towards a sequential pattern $(\rho=0.421$, $\mathrm{p}<0.05)$ though less clearly than for communities of exposed surfaces.

\section{DISCUSSION}

Natural rock surfaces are topographically heterogeneous, commonly including a high proportion of hidden microhabitats. These are subject to distinct environmental conditions, and contribute to the diversity of the subtidal landscape. While most ecological studies have focused on exposed substrata, hidden surfaces may support different assemblages, potentially contributing to substantial differences in function and diversity (Richter et al., 2001).

During the 27-month in situ experiment described above, exposed surfaces were colonised by algae and several invertebrates. Colonial forms were dominant in terms of coverage at the end of the experiment. In contrast, hidden surfaces consistently failed to be colonised by any type of algae. Other studies have demonstrated similar reduced algal coverage in hidden and shaded habitats (e.g. Duggins et al., 1990; Glasby, 2000), and the reduced light intensity is mentioned as a likely cause. However, on artificial plots installed in the temperate subtidal system off southern Australia encrustations of corallines have been thriving, even under shaded conditions (Connell, 2005). This may be due to the relatively shallow deployment of artificial substrata in the latter study, at just 3-5 m water depth. Light intensity may not have fallen below the physiological threshold of algal survival in that particular case.

In the present study bryozoans dominated the hidden substratum, in agreement with observations from other experiments using hidden plots, where bryozoans were conspicuous settlers (e.g. Duggins et al., 1999; Glasby, 1999b). This distributional pattern reflects the negative phototaxic behaviour of 
bryozoan larvae during settlement (Duggins et al., 1999; Glasby, 1999b).

The limpet Trochita calyptraeaformis was observed exclusively on hidden surfaces. This may be explained by the behaviour of the juvenile (Navarro and Chaparro, 2002; Chaparro et al., 2004), which crawls and grazes on biofilm and detritus deposited on rock surfaces, before settling to begin in life as a sessile and suspension-feeding adult (Navarro and Chaparro, 2002; Chaparro et al., 2004). The hidden surfaces on which $T$. calyptraeaformis were found exclusively were dominated by the flat bryozoan $M$. isabelleana. On exposed surfaces the presence of the large, mound-shaped barnacle B. flosculus and the erect bushy bryozoan $L$. variabilis may hinder the movements and grazing of juvenile limpets. Another factor in the preference of $T$. calyptraeaformis for cryptic habitats, suggested by our observations on inter- and subtidal rock habitats, may be the protection offered by such cracks and crevices from predatory sea stars. Future studies are needed to show whether early settling $T$. calyptraeaformis may attract further specimens to form aggregations, which are frequently observed under boulders in the intertidal and shallow subtidal zone (Gallardo, 1977; Chaparro et al., 1998).

Another notable difference between the two microhabitats is the strong preference of the barnacle B. flosculus for exposed surfaces: settlement on the hidden side of the experimental panels was very scarce. In general, barnacle larvae exhibit positive phototaxis (Barnes and Klepal, 1972) and thus prefer open and exposed surfaces for settlement (e.g. Connell, 1985). The initial abundance is further enhanced by a gregarious tendency whereby larvae from subsequent waves of recruitment are encouraged to settle among conspecifics (Matsumura et al., 2000). Differences in species composition on exposed and hidden surfaces lead to dissimilar patterns of coverage during the successional sequence. On exposed surfaces, the pioneer bryozoan $M$. isabelleana was subsequently outcompeted by encrusting red corallines and the barnacle B. flosculus. Thus, exposed communities display a competitive hierarchy, eventually dominated by the late colonizing $L$. variabilis, whose ability to suppress competitively inferior organisms is an important factor in the late successional sequence. This is in line with observations from other subtidal habitats, in which dominant colonial species (e.g. poriferans, hydrozoans, and corals) overgrow subordinate species by lateral expansion (Jackson, 1977; Teixidó et al., 2007). On hidden surfaces, the bryozoan $M$. isabelleana benefited from the absence of competitively superior taxa throughout the experiment, despite the subsequent recruitment of $D$. mejillonensis and $B$. flosculus. No overgrowth was observed, so competitive exclusion was not detected. L. variabilis was recorded on hidden surfaces at the end of the experiment but in much lower abundance than on the exposed surfaces. However, it is likely that over time colonies will continue to grow and spread out, and that ultimately overgrowth may occur. This would indicate a slower successional sequence in hidden habitats than on exposed substrata. Likewise, the interactions between algae and invertebrates are critical in the dynamics of space occupancy, but in hidden habitats the absence of algae can alleviate competition for space (Glasby, 1999a,b; Baynes, 1999; Miller and Etter, 2008), which presumably is another factor slowing down the rate of succession.

In conclusion, the successional sequences differed substantially between exposed and hidden habitats during the 27-month in situ experiment. In natural systems, such differences will contribute to overall biodiversity, as pioneer species unable to survive long periods on exposed surfaces may be able to persist on hidden surfaces, from where they may expand by lateral growth to exposed surfaces or migrate when size-specific thresholds are overcome (e.g. Sommer et al., 1999). In particular, hidden communities may also be part of important energy and material pathways (Richter et al., 2001) but they are often ignored, as most succession studies have focused on exposed plain surfaces. We suggest that future studies on ecological processes and community succession on hard-bottom substrata should also include hidden communities, because these may have an important influence on local community composition and structure.

\section{ACKNOWLEDGEMENTS}

We are grateful to T. Ashton, M. Cáceres, I. Fiorillo, C. Guerra, I. Marín, S. Rossi, R. Saavedra, P. Schubert, A. Silva, V. Toro, J. Vélez and M. Weiss for their support during diving. Two anonymous reviewers provided constructive comments on the manuscript. This study was conducted in the framework of the EU-funded FP6-INCO-STREP project, "Climate Variability and El Niño-Southern Oscilla- 
tion: Implications for Natural Coastal Resources and Management" (CENSOR-I-CT-2004-511071) and the Programa Bicentenario de Ciencia y Tecnologia RUE-02. This is CENSOR publication $\mathrm{N}^{\circ} 380$.

\section{REFERENCES}

Barnes, H. and W. Klepal. - 1972. Phototaxis in stage I nauplius larvae of two cirripedes. J. Exp. Mar. Biol. Ecol., 10: 267-273.

Baynes, T.W. - 1999. Factors structuring a subtidal encrusting community in the southern Gulf of California. Bull. Mar. Sci., 64: 419-450.

Bourget, E., J. De Guise and G. Daigle. - 1994. Scales of substratum heterogeneity, structural complexity, and the early establishment of a marine epibenthic community. J. Exp. Mar. Biol. Ecol., 181: 31-51.

Burnaford, J.L. - 2004. Habitat modification and refuge from sublethal stress drive a marine plant-herbivore association. Ecology, 85: 2837-2849.

Chaparro, O.R., I. Bahamondes-Rojas, A.M. Vergara and A.A. Rivera. - 1998. Histological characteristics of the foot and locomotory activity of Crepidula dilatata Lamarck (Gatropoda: Calyptreidae) in relation to sex changes. J. Exp. Mar. Biol. Ecol., 223: 77-91.

Chaparro, O.R., C.J. Segura, R.J. Navarro and R.J. Thompson. 2004. The effect of food supply on feeding strategy in sessile female grastropods Crepidula fecunda. Mar. Biol., 144: 79-87.

Cifuentes, M., C. Kamlah, M. Thiel, M. Lenz and M. Wahl. - 2007. Effects of temporal variability of disturbance on the succession in marine fouling communities in northern-central Chile. J. Exp. Mar. Biol. Ecol., 352: 280-294.

Clarke, K.R. - 1993. Non-parametric multivariate analyses of changes in community structure. Aust. J. Ecol., 18: 117-143.

Clarke, K.R. and R.N. Gorley. - 2006. PRIMER v6: User Manual/ Tutorial, PRIMER-E: Plymouth.

Connell, J.H. - 1985. The consequences of variation in initial settlement vs. post-settlement mortality in rocky intertidal communities. J. Exp. Mar. Biol. Ecol., 93: 11-45.

Connell, S.D. - 2005. Assembly and maintenance of subtidal habitat heterogeneity: synergistic effects of light penetration and sedimentation. Mar. Ecol. Prog. Ser., 289: 53-61.

Coyer, J.A., R.F. Ambrose, J.M. Engle and J.C. Carrol. - 1993. Interactions between corals and algae on a temperate zone rocky reef: mediation by sea urchins. J. Exp. Mar. Biol. Ecol., 167: 21-37.

Dexter, S.C. and K.E. Lucas. - 1985. The study of biofilm formation under water by photoacoustic spectroscopy. J. Colloid. Interf. Sci., 104: 15-27.

Duggins, O.D., J.E. Eckman and A.T. Sewell. - 1999. Ecology of understory kelp environments. II. Effects of kelps on recruitment of benthic invertebrates. J. Exp. Mar. Biol. Ecol., 143: 27-45.

Escribano, R., V. Marín, P. Hidalgo and G. Olivares. - 2002. Physical-biological interactions in the pelagic ecosystem of the nearshore zone of the northern Humboldt Current System. In: J.C. Castilla and J. Largier (eds.), The Oceanography and Ecology of the Nearshore Bays in Chile. Proceedings of the International Symposium on Linkages and Dynamics of Coastal Systems: Open Coast and Embayments, pp: 145-175. Eds. Univ. Católica Chile, Santiago.

Gallardo, C. - 1977. Two modes of development in the morphospecies Crepidula dilatata (Gastropoda: Calyptraeidae) from Southern Chile. Mar. Biol., 39: 241-251.

Glasby, T.M. - 1999a. Effects of shading on subtidal epibiotic assemblages. J. Exp. Mar. Biol. Ecol., 234: 275-290.

Glasby, T.M. - 1999b. Interactive effects of shading and proximity to the seafloor on the development of subtidal epibiotic assemblages. Mar. Ecol. Prog. Ser., 190: 113-124.

Glasby, T.M. - 2000. Surface composition and orientation interact to affect subtidal epibiota. J. Exp. Mar. Biol. Ecol., 248: 177-190.

Glasby, T.M. and S.D. Connell. - 2001. Orientation and position of substrata have large effects on epibiotic assemblages. Mar.
Ecol. Prog. Ser. 214: 127-135.

Irving, A.D. and S.D. Connell. - 2002. Sedimentation and light penetration interact to maintain heterogeneity of subtidal habitats: algal versus invertebrate dominated assemblages. Mar. Ecol. Prog. Ser., 245: 83-91.

Jackson, J.B.C. - 1977. Competition on marine hard substrata: the adaptive significance of solitary and colonial strategies. Am. Nat., 111: 743-767.

Matsumura, K., J.M. Hill, P.O. Thomason, J.C. Thomason and A.S. Clare. - 2000. Discrimination at settlement in barnacles: laboratory and field experiments on settlement behaviour in responses to settlement-inducing protein complexes. Biofouling, 16: 181-190.

Melville, A.J. and S.D. Connell. - 2001. Experimental effects of kelp canopies on subtidal coralline algae. Austral Ecol., 26: 102-108.

Miller, R.J. and R. Etter. - 2008. Shading facilitates sessile invertebrate dominance in the rocky subtidal Gulf of Maine. Ecology, 89: 452-462

Navarro, J.M. and O.R. Chaparro. - 2002. Grazing-filtration as feeding mechanisms in motile specimens of Crepidula fecunda (Gastropoda: Calyptraeidae). J. Exp. Mar. Biol. Ecol., 270: 111-122.

Navarrete, S.A. and J.C. Castilla. - 2003. Experimental determination of predation intensity in an intertidal predator guild: dominant versus subordinate prey. Oikos, 100: 251-262.

Navarrete, S.A., M. Parragué and E.A. Wieters. - 2008. Local and meso-scale patterns of recruitment and abundance of two intertidal species that compete for refuges. Mar. Biol., 155: 223-232.

Pacheco, A. and J. Laudien. - 2008. Dendropoma mejillonensis sp. nov. new species of vermetid (Mollusca, Caenogastropoda) from northern Chile. The Veliger, 50: 219-224.

Raimondi, P.T. and A.N.C. Morse. - 2000. The consequences of complex larval behaviour in a coral. Ecology, 81: 3193-3211.

Richter, C., M. Wunsch, M. Rasheed, I. Kötter and M. Badran. 2001. Endoscopic exploration of Red Sea coral reefs reveals dense populations of cavity-dwelling sponges. Nature, 413: 726-730.

Rodríguez, S.D., F.P. Ojeda and N.C. Inestrosa. - 1993. Settlement of benthic marine invertebrates. Mar. Ecol. Prog. Ser., 97: 193-207.

Roleda, M.Y., C. Wiencke, D. Hanelt and K. Bischof. - 2007. Sensitivity of the early life stages of macroalgae from the northern hemisphere to ultraviolet radiation. Photochem. Photobiol., 83: 851-862.

Sebens, K.P. - 1986. Spatial relationships among encrusting marine organisms in the New England subtidal zone. Ecol. Monogr., 56: 73-96.

Siddon, C.E. and J.D. Witman. - 2004. Behavioral indirect interactions: multiple predator effects and prey switching in the rocky subtidal. Ecology, 85: 2938-2945.

Sommer, U., B. Meusel and C. Stielau. - 1999. An experimental analysis of the importance of body-size in the seastar-mussel predator-prey relationship. Acta Oecol., 20: 81-86.

Teixidó, N., J. Garrabou, J. Gutt and W. Arntz. - 2007. Iceberg disturbance and successional spatial patterns: the case of the shelf Antarctic benthic communities. Ecosystems, 10: 142-157.

Underwood, A.J. and M.G. Chapman. - 2006. Early development of subtidal macrofaunal assemblages: relationships to period and timing of colonization. J. Exp. Mar. Biol. Ecol., 330: 221-233.

Valdivia, N., A. Heidemann, M. Thiel, M. Molis and M. Wahl. 2005. Effects of disturbance on the diversity of hard-bottom macrobenthic communities on the coast of Chile. Mar. Ecol. Prog. Ser., 299: 45-54.

Villegas, M.J., J. Laudien, W. Sielfeld and W.E. Arntz. - 2008. Macrocystis integrifolia and Lessonia trabeculata (Laminariales; Phaeophyceae) kelp habitats structures and associated macrobenthic community off northern Chile. Helgoland Mar. Res., 62 (Suppl 1): 33-43.

Witman, J.D. and P.K. Dayton. - 2001. Rocky subtidal communities. In: M.D. Bertness, S.D. Gaines and M.E. Hay (eds.) Marine Community Ecology, pp: 339-366. Sinauer Associates Inc, Sunderland, Massachusetts.

Yund, P.O., S.D. Gaines and M.D. Bertness. - 1991. Cylindrical tube traps for larval sampling. Limnol. Oceanogr., 36: 11671177.

Scient. ed.: M.P. Olivar.

Received December 12, 2008. Accepted April 28, 2009.

Published online November 30, 2009. 